十二指腸乳頭部癌の臨床病理学的研究

一予後規定因子と再発様式について一

東京女子医科大学消化器外科学教室 (指導 : 羽生富士夫教授)

新井田達 雄

\title{
A CLINICOPATHOLOGICAL STUDY ON CARCINOMA OF THE PAPILLA VATER WITH SPECIAL REFERENCE TO FACTORS INFLUENCING ITS PROGNOSIS AND RECURRENT MODE
}

Tatsuo ARAIDA

(Professor and Chairman: Fujio Hanyu)

Department of Gastroenterological Surgery, Tokyo Women's Medical College

乳頭部癌67例を対象に, 胆道癌規約の項目について，生存期間への影響の大きさをCox の比例八 ザード法で解析し予後規定因子を検討した。ささらに, 再発様式を再手術, 剖検, 画像診断から検討乙 た。有意な予後規定因子は，リンパ節転移々膵缄漫潤であった。十二指腸，膵臓浸潤之脈管浸潤，リ ンパ節転移，肉眼型は強い相関を示し，膵臓浸潤を認めると潰瘍形成群が増加し，神経周囲浸潤も認 めた。 (144腸間膜根部リンパ節に $22.3 \%$ 之高率に転移を認めた。再発様式は同リンパ節再発が $19.4 \%$ と 特徵的であった。とくに膵蔵浸潤がない例では, リンパ節転移が予後を規定し, 晚期に同リンパ節に 再発した。膵臟浸潤例は，リンパ節転移にかかわらず予後不良で，血行性転移も認め， $75.0 \%$ 早期 に再発した。

索引用語：十二指腸乳頭部癌, 乳頭部癌予後規定因子, 乳頭部癌リンパ節転移, 乳頭部癌膵臓浸潤, 乳頭部癌の(14腸間膜根部リンパ節再発

\section{緒言}

十二指腸乳頭郎癌 (以下乳頭部癌) は, 膵・胆道の 悪性腫瘍の中では切除率, 生存率ともに良好で外科治 療成績を最む期待できる癌である1)。また最近, 超音波 内視鏡などの画像診断の進歩にともない, 術前に癌の 存在診断のみならず進展度までも予測することが可能 となりつつある ${ }^{2 / 3)}$. 膵癌の拡大郭清手術の概念の導 入4), 術前・術後管理の進歩(5) とよって, 治癒切除率が 向上し手術死亡率が低下した。しかし治瘾切除例のう ちで，早期に再発するものもあれば，一方では比較的 晚期に再発するものもあり, 臨床病理学的に十分検討 された報告はない，特に予後規定因子，再発様式の特 徵は十分に解明されていないのが現状である。予後規 定因子を明らかにし，再発様式の特徵を正確に把握し

$<1989$ 年 3 月 8 日受理>別刷請求先: 新井田達雄 干162 新宿区河田町 8-1 東京女子医科大学消化 器病センター外科
て初めて外科治療に反映し，遠隔成績の向上につなが る. そこで本研究において, 胆道癌取扱い規約 ${ }^{6}$ (以下 規約）の乳頭部癌の遠隔成績に影響をおよ括すと思わ れた項目から，予後規定因子を統計学的に解析し，さ らに再発様式の特徵を検討した。

\section{対象}

1968年 1 月から1988年 6 月までに東京女子医科大学 消化器外科学教室で経験した乳頭部癌は, 102例で切除 例は96例，切除率 $94.1 \%$ たった。そのうち治疮切除 は 85 例, 治癒切除率 $88.5 \%$, 手術死亡は 7 例, 手術死 亡率7.3\%であった。

今回対象としたのは, 102例のうち, 非切除 3 例, 非 手術 3 例, 非治㾤切除11例, 手術死亡 7 例, 明らかな 他病死 12 例, 乳頭部切除 3 例, 重複癌 1 例を除 $<, 67$ 例である(除外症例に重複 5 例あり)，対象の性別は男 38 例, 女29例，年齢は33 81歳，平均年粉は $58.87 \pm$ 9.53 (Mean土SD) であった。 
図 1 膵藏浸潤の規定（ panc $_{1} \alpha, \operatorname{panc}_{1} \beta$ の提唱）

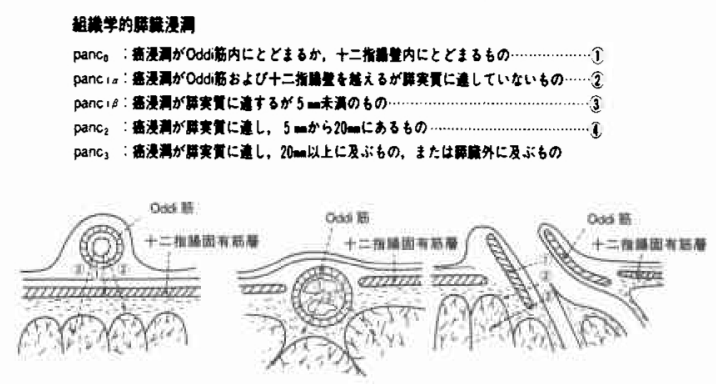

方 法

1. 予後規定因子

1) 検討項目

規約より（1）〜（10）の項目を選び予後規定因子に 関する検討項目とした，さらに臨床的および統計学的 見地より各項目を2 2 のカテゴリーに区分した。記 載法は規約に基ついて表記した。

（1）組織学的膵蔵浸潤 (以下膵葴浸潤)：本研究にお いて, 規約上の膵藏浸潤をさらに厳密に規定し, panc 1 （癌漫潤が Oddi筋および十二指腸壁を越觉るが膵実 質に達していないもの，または癌浸潤が膵実質に達す るが $5 \mathrm{~mm}$ 末満のもの）を， $\mathrm{panc}_{1} \alpha$ (膵実質に達しない もの）と $\mathrm{panc}_{1} \beta$ (膵実質に達するが $5 \mathrm{~mm}$ 末満のもの) に分け, (1) $\mathrm{panc}_{0}$, (2) $\mathrm{panc}_{1} \alpha$, (3) $\mathrm{panc}_{1} \beta$, (4) $\mathrm{panc}_{2,3}$ に 区分した（図 1).

（2）組織学的十二指腸浸潤 (以下十二指腸浸潤)：十 二指腸浸潤を $\mathrm{d}_{0}$ と $\mathrm{d}_{1}, \mathrm{~d}_{2}$ と $\mathrm{d}_{3}$ では注注同様の予後が 得られたので，(1) $\mathrm{d}_{0} \mathrm{~d}_{1}$ ，(2) $\mathrm{d}_{2} \mathrm{~d}_{3}$ に区分した。

（3）リンパ節転移：(1) $\mathrm{n}(-)$, (2) $\mathrm{n}(+)$ に区分し た。

（4）肉眼型：(1)腫瘤形成群（非露出腫瘤型, 露出腫 瘤型, 腫瘤潰瘍型およびポリープ型), (2)潰瘍形成群(潰 瘍腫瘤型および潰瘍型）とに区分した。

（5）組織型：(1)乳頭腺癌と(2)その他（管状腺癌, 力 ルチノイド腫瘍）とに区分した。

（6）癌の周囲組織に対する浸潤增殖様式：(1) INF $\alpha$, (2) INF $\beta$ ，(3) INF $\gamma$ に区分した.

（7）リンパ管浸潤：(1) ly (-)，(2) ly (+)に区分し た。

（8）静脈浸潤：(1) v（一)，(2) v（十）に区分した。

（9）腫瘍の大きさ：腫瘍の最大径で, (1)0 2.0cm, (2) $2.1 \sim 4.0 \mathrm{~cm}$, (3) $4.1 \mathrm{~cm}$ 以上に区分した.

（10）リンパ節郭清の程度：(1) $\mathrm{R}_{1}$ は第 1 群のリンパ
節郭清のみを行ったもの，(2) $\mathrm{R}_{2,3}$ は規約で規定された， 第 1 〜 群のリンパ節郭清を行ったものまたは第 1 ー 3 群のリンパ節郭清をおこなったもの，(3) $\mathrm{R}_{2,3} *$ は $\mathrm{R}_{2,3}$ のリンバ節郭清に加え, とくに(14)腸間膜根部リン パ節郭清を重点的に行ったものに区分した。

2) 10 項目の各カテゴリー別の累積生存率(以下生存 率)を Kaplan-Meier 法で算出し, 単独の生存率を検討 した。各カテゴリー間の生存率の有意差検定は 3 群以 上の検定が可能な Logrank 検定で行った。

3）各項目が術後生存期間に与舜影響の大きさや 臨床的意義の解析には，Cox の比例ハザード法を用い た.

4）各項目間相互の関係についてはカテゴリ一間の 相関を求めることができるSpearmanの連関係数を 用いた。

2. 再発様式

1）再発様式の確認は再手術時の手術所見，剖検診 断, 画像所見より行った.

2）治癒切除となった下部胆管癌19例， $2 \mathrm{~cm}$ 以下の 小膵頭部膵管癌15例と再発様式を比較した。

3）脺缄, 十二指腸への進展度別とリンパ節転移の有 無による再発様式の特徵を検討した。

\section{結 果}

1. 予後規定因子

1) 対象67例の生存率

1 年生存率は $90.9 \%, 3$ 年生存率 $67.2 \%, 5$ 年生存 率55.1\%であった（図 2 )。

2) 単独項目の生存率

（1）膵臓漫潤：5 年生存率は panc $_{0} 82.6 \%$, panc $_{1} \alpha$ $71.4 \%, \operatorname{panc}_{1 \beta} \beta 0 \%$, panc $_{2,3} 27.8 \%$ であった。これ らのカテゴリー別生存率に有意差を認めた（p= near0)（図 3 ).

（2）十二指腸浸潤： 5 年生存率は， $\mathrm{d}_{0}, \mathrm{~d}_{1} 81.8 \%$, $\mathrm{d}_{2}, \mathrm{~d}_{3} 40.4 \%$ で 2 つのテゴリ一別生存率に有意差を 認めた ( $\mathrm{p}=0.002)$ (図 4 ).

（3）リンパ節転移：5 年生存率は， $\mathrm{n}$ (一) $73.5 \%$, $\mathrm{n}(+) 24.6 \%$ で 2 つのカテゴリー別生存率に有意差を 認めた（p=near0）（図 5 ）.

（4）肉眼型：5 年生存率は，腫瘤形成群 $65.7 \%$, 潰 癔形成群 $27.7 \%$ で 2つカテゴリー別生存率に有意差 を認めた（p=0.004）（图6）。

（5）組織型：5 年生存率は, 乳頭腺癌 $60.5 \%$ ，その 他 $47.3 \%$ で，2つのカテゴリー別生存率に有意差は認 められなかった（p=0.451）。 
図 2 乳頭部癌の累積生存率

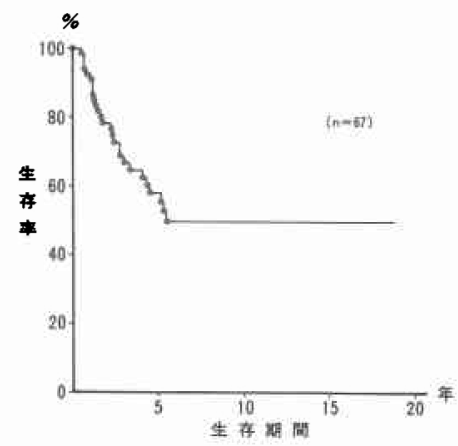

図 3 膵臓浸潤度別の累積生存率 Logrank 検定統計量 : $25.00, \mathrm{p}:$ near0

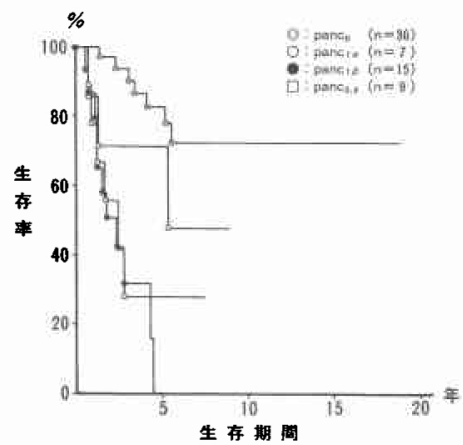

図 4 十二指腸浸潤度別の累積生存率 Logrank 検定統計量：9.66, p : 0.002

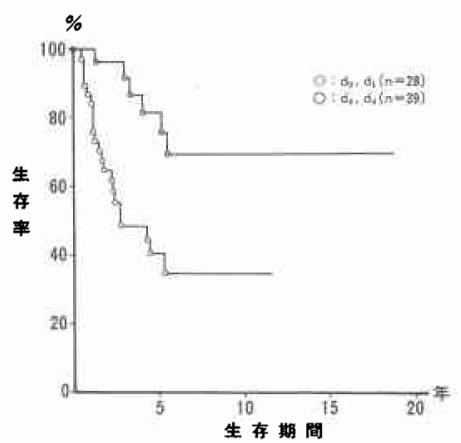

（6）浸潤増殖様式： 5 年生存率は, INF $\alpha 100 \%$, INF $\beta$ 56.6\%, INF $\gamma 20.0 \%$ で，3つのカテゴリー別 生存率に有意差は認められなかった（p=0.08）.

（7）リンパ管浸潤：5 年生存率は，1y（一) $83.9 \%$, ly(+) 49.8\%で，2つのカテゴリ一別生存率に有意差 を認めた（ $p=0.029 ）($ 図 7 ).

（8）静脈浸潤： 5 年生存率は, $\mathrm{v}(-) 61.1 \%, \mathrm{v}(+)$
図 5 リンパ節転移別の累積生存率 Logrank 検定統計量 : $16.12, \mathrm{p}:$ near 0

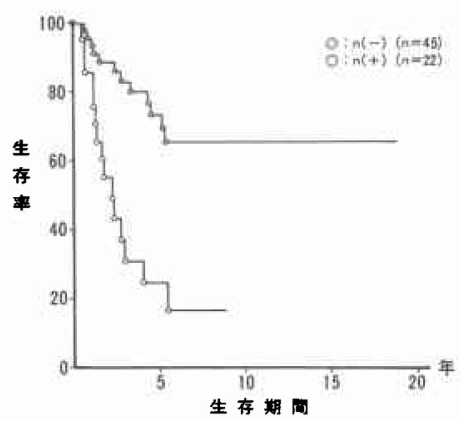

図 6 肉眼型別の累積生存率 Logrank 検定統計量: $8.28, \mathrm{p}: 0.004$

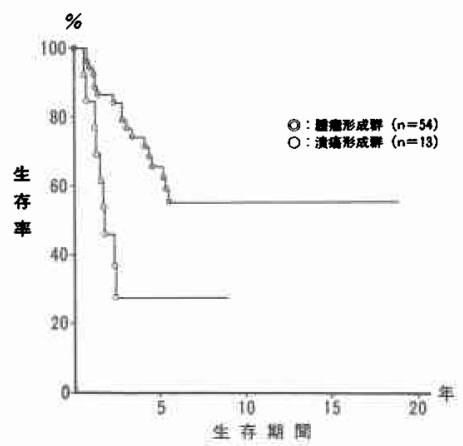

図 7 リンパ管浸潤別の累積生存率 Logrank 検定統計量 : 4.77, p : 0.029

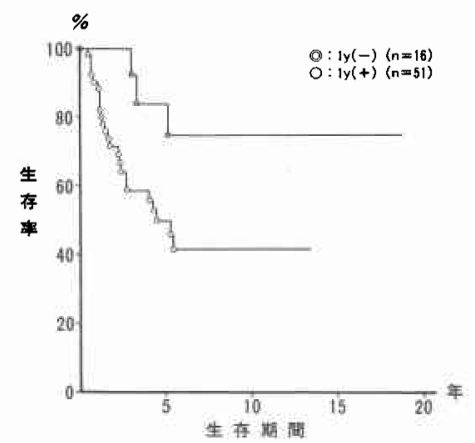

$54.8 \%$ で，2つのカテゴリー別生存率に有意差を認め なかった（ $\mathrm{p}=0.123 ）$.

（9）腫瘍の大きさ：5 年累積生存率は, 0 $2 \mathrm{~cm}$ $69.4 \%, 2.1 \sim 4.0 \mathrm{~cm} 50.5 \%, 4.1 \mathrm{~cm}$ 以上 $46.9 \%$ で, 3 つのカテゴリー別生存率に有意差を認めなかった $(\mathrm{p}=0.365)$.

（10）リンパ節郭清度：5 年生存率は， $R_{1} 50.0 \%$, 
図 8 リンパ節郭清度別累積生存率

Logrank 検定統計量 : $1.87, \mathrm{p}: 0.393$

*(14)腸間膜根部リンバ節郭清例

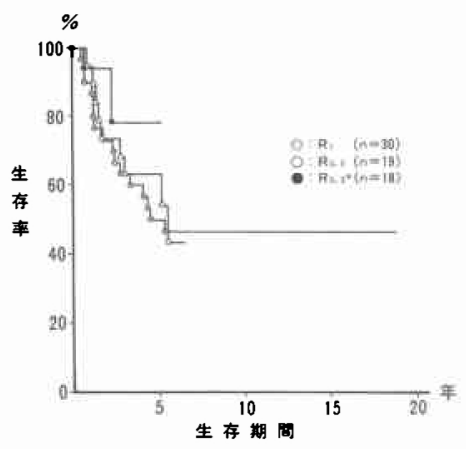

$\mathrm{R}_{2,3} 63.2 \%, \mathrm{R}_{2,3} * 78.4 \%$ で，3つのカテゴリ一別生 存率に有意差を認めなかった（p=0.393）（図 8).

ただし，生存率は 5 年以降ほぼ同一なので 5 年生存 率をもって記載した。

3）各項目が術後生存期間へおよぼす影響

10項目が術後生存期間におよばす影響の大きさを， Cox の比例ハザード法により解析した，有意性検定の 指標となる $\chi^{2}$ 值でみると,リンパ節転移が24.873と最 大で, 術後生存期間に最も有意な影響をおよぼし( near 0)，次に膵蔵浸潤14.812であった $(\mathrm{p}=0.002)$. 他の項目の $\chi^{2}$ 値は小さく, 有意な影響はなかった $(\mathrm{p}>$ 0.1). 各カテゴリーの予後への重みは回㷌係数で表わ され，マイナスは予後良好に，プラスでは予後不良に 作用することを示している、リンパ節転移で $\mathrm{n}($ (一)の 回㷌係数はー0.620で予後に対して良好に作用するこ とを示し， $\mathrm{n}(+)$ の回帰係数は1.359とプラスに大き く作用し予後不良なことを示した，膵臓浸潤項では panc $_{0}, \operatorname{panc}_{1} \alpha$ が回帰係数 $-0.549,-0.011$ とイナス に作用し予後良好であることを示したのに対して， panc $_{1} \beta$ が1.337と大きくプラスに作用し panc $_{1} \beta$ を境 に予後がきわめて不良であることを示した、リンパ節 郭清度, 浸潤増殖様式, 組織型, 腫晹の大きさ, 静脈 浸潤，リンパ管浸潤，肉眼型，十二指腸浸潤の順に各 項目の $\chi^{2}$ 値は小さく, 有意性は少なくなり, 術後生存 期間への影響が小さくなることを示した（表 1 ）.

なお，全10項目を考慮し，因子間の偏りを補正して 算出した Cox の比例ハザード法による推定生存率曲 線と Kaplan-Meier 法による実測生存率曲線の解離は 少なく長期にわたり良く一致した（図９）。

4) 規約項目相互の関係
表 1 Coxの比例ハザード法による項目別生存期間 への影響

\begin{tabular}{|c|c|c|c|c|}
\hline 暗 盲 & カテエリー & 露的数 & 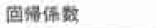 & 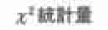 \\
\hline 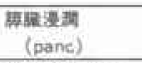 & $1_{3}^{0}{ }_{3}$ & $\begin{array}{r}36 \\
15 \\
4\end{array}$ & $\begin{array}{l}-0.549 \\
-0.011 \\
-0.023 \\
\end{array}$ & $\begin{array}{l}14.812 \\
(D=0.002)\end{array}$ \\
\hline 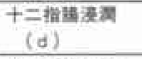 & $\begin{array}{l}0.1 \\
2.3 \\
\end{array}$ & $\begin{array}{l}28 \\
39 \\
\end{array}$ & $\begin{array}{r}0.007 \\
-0.005 \\
\end{array}$ & $\begin{array}{l}0.001 \\
(D=0.981)\end{array}$ \\
\hline 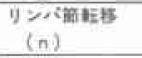 & $\begin{array}{l}(-) \\
(+)\end{array}$ & $\begin{array}{l}45 \\
22 \\
\end{array}$ & $\begin{array}{r}-0.620 \\
1.359\end{array}$ & $\begin{array}{l}24.073 \\
(p=\text { near } 0)\end{array}$ \\
\hline 诗典整 & 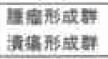 & $\begin{array}{l}54 \\
13 \\
\end{array}$ & $\begin{array}{r}0.003 \\
-0.014 \\
\end{array}$ & $\begin{array}{l}0.002 \\
(P=0.968)\end{array}$ \\
\hline 殂 视 & 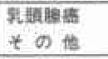 & $\begin{array}{l}52 \\
15 \\
\end{array}$ & $\begin{array}{r}-0,132 \\
0,459 \\
\end{array}$ & $\begin{array}{l}1.758 \\
(D=0.184)\end{array}$ \\
\hline 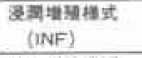 & $\stackrel{g}{\pi}$ & \$1 & $\begin{array}{r}-1990 \\
8.971 \\
\end{array}$ & $\begin{array}{l}3.898 \\
(P=0.143)\end{array}$ \\
\hline 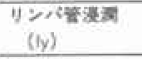 & $\begin{array}{l}(-) \\
1+1\end{array}$ & $\begin{array}{l}16 \\
51 \\
\end{array}$ & $\begin{array}{r}-0.067 \\
0.021 \\
\end{array}$ & $\begin{array}{l}0.020 \\
(p=0.888)\end{array}$ \\
\hline $\begin{array}{l}\text { Buspara } \\
(v)\end{array}$ & $\begin{array}{l}(-) \\
(+)\end{array}$ & $\begin{array}{l}36 \\
31 .\end{array}$ & $\begin{array}{r}0.104 \\
-0.120 \\
\end{array}$ & $\begin{array}{l}0.328 \\
(P=0.567)\end{array}$ \\
\hline 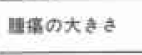 & $2:-2=0=$ & $\begin{array}{r}32 \\
27 \\
8\end{array}$ & $\begin{array}{rl}-0 & 1145 \\
0: 183 \\
0.128\end{array}$ & $\begin{array}{l}0.442 \\
(D=0.802)\end{array}$ \\
\hline 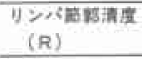 & $\begin{array}{l}\mathbf{R}_{4} \\
\mathbf{R}_{2}: \text { : } \\
\mathbf{R}_{2}\end{array}$ & 预最 & $\begin{array}{r}9018 \\
-8.981 \\
-8.74 \\
\end{array}$ & $\begin{array}{l}4.329 \\
(P=0.115)\end{array}$ \\
\hline
\end{tabular}

図 9 Kaplan-Meier 法による実測生存率および比例 ハザード法による推定生存率

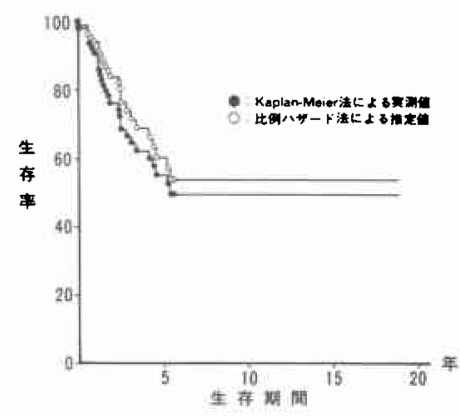

（1）膵葴浸潤，十二指腸浸潤と脈管浸潤，神経周囲 浸潤, リンパ節転移

$\mathrm{d}_{0}$ panc $_{0}$ は脈管浸潤は認めず, 全例 $\mathrm{n}($ ( )であった。 $\mathrm{d}_{1}$ panc $_{0}$ では ly (+) $57.9 \%, \mathrm{v}(+) 31.6 \%, \mathrm{n}(+)$ $22.1 \%$ であった. panc $_{1} \beta$ は $\mathrm{ly}(+) 100 \%, \mathrm{v}(+) 60.0 \%$, $\mathrm{pn}(+) 20.0 \%, \mathrm{n}(+) 46.7 \%$ であった.ささらに, panc ならびに $\mathrm{d}$ の進展度と $\mathrm{ly}, \mathrm{v}, \mathrm{n}$ の陽性率の相関を Spearmanの連関係数で求めると有意の相関を示した $(\mathrm{p}<0.001)($ 表 2$)$.

（2）膵臓浸潤，十二指腸漫潤と肉眼型

対象67例を規約に準じて肉眼的分類を行い, panc と $\mathrm{d}$ との関係を検討した. $\mathrm{d}_{0} \mathrm{panc}_{0} 9$ 例は, 非露出腫瘤 2 例, 露出腫瘤 4 例, 腫瘤潰瘍型 1 例, ポリープ型 2 例 で全例腫瘤形成群で潰瘍形成群は認めなかった，膵蔵 浸潤( $\mathrm{panc}_{1} \beta, \mathrm{panc}_{2,3}$ )を認めると，潰汪形成群か $40 \%$ 以上に堌加した. pancならびに d の進展度と潰瘍形成 
表 2 膵臓浸潤, 十二指腸浸潤と脈管浸潤，神経周团 浸潤,リンパ節転移

\begin{tabular}{|c|c|c|c|c|c|}
\hline & 例数 & $y(+)^{*}$ & $v(+)^{*}$ & $\mathrm{pn}(+)$ & $n(t)^{*}$ \\
\hline$d_{0}$ panc $_{0}$ & 9 & $0 \%$ & $0 \%$ & $0 \%$ & $0 \%$ \\
\hline$d_{1}$ panco $_{0}$ & 19 & $57.9 \%$ & $31.6 \%$ & $0 \%$ & $22.1 \%$ \\
\hline$d_{2}$ panco & 8 & $100 \%$ & $37.5 \%$ & $0 \%$ & $25.0 \%$ \\
\hline$d_{2}$ panc $1 \alpha$ & 7 & $100 \%$ & $71.4 \%$ & $0 \%$ & $42.9 \%$ \\
\hline $\mathrm{d}_{2 \sim 3}$ panc $1 / \beta$ & 15 & $100 \%$ & $60.0 \%$ & $20 \%$ & $46.7 \%$ \\
\hline$d_{2 \sim 3}$ panc $_{2 \sim 3}$ & 9 & $100 \%$ & $88.9 \%$ & $0 \%$ & $66.7 \%$ \\
\hline 計 & 67 & $74.6 \%$ & $46.3 \%$ & $4.5 \%$ & $31.3 \%$ \\
\hline
\end{tabular}

表 3 膵臓浸潤, 十二指腸浸潤と肉眼型

\begin{tabular}{|c|c|c|c|c|c|c|c|c|c|}
\hline & \multirow{3}{*}{ 點踖 } & \multicolumn{5}{|c|}{ 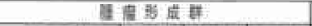 } & \multicolumn{3}{|c|}{ 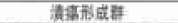 } \\
\hline & & \multicolumn{2}{|c|}{ H } & \multirow{2}{*}{ 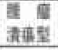 } & \multirow{2}{*}{ 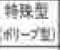 } & \multirow{2}{*}{ 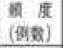 } & \multirow{2}{*}{ 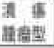 } & \multirow{2}{*}{ ath } & \multirow{2}{*}{ 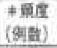 } \\
\hline & & 非要直 & 馬 出 & & & & & & \\
\hline the parce & 9 & 2 & 4 & 1 & 2 & $\begin{array}{c}100 \% \\
(9)\end{array}$ & & & $0 \%$ \\
\hline$d_{f}$ pance & 19 & 2 & 13 & 4 & & $\begin{array}{c}100 \% \\
(19)\end{array}$ & & & $0 \%$ \\
\hline di pance & 8 & & 4 & 3 & & $\begin{array}{c}87,5 \% \\
(7)^{2}\end{array}$ & 1 & & $12.5 \%$ \\
\hline$d_{1}= \pm$ panc la & 7 & 2 & 2 & 1 & & $\begin{array}{c}71,486 \\
(53) \\
\end{array}$ & 2 & & $\begin{array}{c}28.6 \% \\
(2)\end{array}$ \\
\hline dite pane is & 15 & & 5 & 4 & & $\begin{array}{c}60,0 \% \\
(9)\end{array}$ & 5 & 1 & $\begin{array}{c}40.0 \% \\
(6)\end{array}$ \\
\hline$d_{2}=4$ panc:-1 & 9 & 1 & 8 & 1 & & $\begin{array}{c}55.6 \% \\
(3)\end{array}$ & 1 & 3 & $\begin{array}{r}44.4 \% \\
(4)\end{array}$ \\
\hline It & 67. & 7 & 31 & 14 & 2 & $\begin{array}{c}80.6 \% \\
(54)\end{array}$ & 9 & 4 & $\begin{array}{r}19.4 \% \\
1.9 \%\end{array}$ \\
\hline
\end{tabular}

の頻度の相関をSpearmanの連関係数を用いて求め ると, 強い相関を示した（p=near 0)（表 3$)$.

2. 再発様式

1）再発様式之平均生存期間

再発は，67例中32例で再発率は47.8\%であった，各 再発様式の再発率, 再発死までの平均生存期間 （Mean士SD）は，(14)腸間膜根部リンパ節再発13例, $19.4 \%, 2.44 \pm 1.81$ 年，肺・肝・骨への血行性転移 13 例， $19.4 \% ， 1.64 \pm 1.10$ 年, 特殊な腹腔内播種（他医 にて胆囊摘出, 胆汁外㾇造設, 経十二指腸的乳頭生検 術後, 脺頭十二指腸切除術をらけ治瘱切除が得られた にもかかわらず播種をさたした例) 6 例, $9.0 \%, 1.45 \pm$ 1.49年であった（表 4 ).

2) 脺頭部領域癌との再発様式の比較

治癒切除となった下部胆管癌 19 例, $2 \mathrm{~cm}$ 以下の小膵 頭部膵管癌15例と再発様式を比較すると, 乳頭部癌に (14)腸間膜根部リンパ節再発が $19.4 \%$ と多かった。下部 胆管癌の再発様式は，全例肝転移で，小膵頭部癌では 肝転移 $33.3 \%$, 後腹膜再発 $20.0 \%$ であった。下部胆管
表 4 再発様式之平均生存期間

\begin{tabular}{|c|c|c|c|}
\hline 再委㙘式 & 湖数 & 再器高( $\%$ ) & 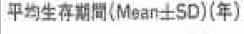 \\
\hline (4)晹間膜㧼部リンバ穊 & 18 & 19.4 & $2.44 \pm 1.81$ \\
\hline 肺・肝・骨転䔟 & 13 & 19.4 & $1.64 \pm 1.10$ \\
\hline 特殊な腹腔内播箠 & 6 & 9.0 & $1.45 \pm 1.49$ \\
\hline It & 32 & 47.8 & \\
\hline
\end{tabular}

表 5 脺頭部領域癌との再発様式の比較

\begin{tabular}{|c|c|c|c|c|c|c|}
\hline & 再皇箭 & 再锤事 & リンバ笽再発 & 肺·朋・骨轻移 & 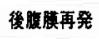 & 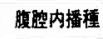 \\
\hline 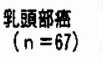 & 32 & $47.8 \%$ & $19.4 \% * *$ & $19.4 \%$ & - & $9.0 \%$ \\
\hline $\begin{array}{c}\text { 下部䏣管富" } \\
(n=19)\end{array}$ & 4. & $21.1 \%$ & - & $21.1 \%$ & - & - \\
\hline 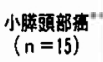 & 8 & $53.3 \%$ & - & $33.3 \%$ & $20.0 \%$ & - \\
\hline
\end{tabular}

*治策切绦となった下部䏣管基

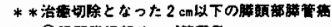

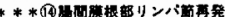

癌，脺頭部癌ともリンパ節転移のみの再発は認めず, 乳頭部癌の(14)腸間膜根部リンパ節再発は特徴的であっ た（表 5 ).

3）膵臓浸潤，十二指腸漫潤，リンパ節転移別の再発 様式

膵葴浸潤を認めない43例中，再発は11例，再発率は $25.6 \%$ であった。 そのうち, n(-)34例の再発は 3 例, 再発率 $8.8 \%$ であったのに対し，n（十）9例の再発は 8 例, 再発率 $88.9 \%$ と有意に高率であった（p< 0.001).とくに術後 5 年以上経過した晚期の再発 4 例 をみると全例(14)腸間膜根部リンパ節再発であった， $\mathrm{d}_{0}$ panc $_{0} 9$ 例はすべて n(一) で，リンパ節郭清の程度に かかわらず全例生存中であり, 最長18年 9 か月の生存 例も認めた(図10-1). 膵臟浸潤を認める24例は全例 $\mathrm{d}_{2}$ 〜 $\mathrm{d}_{3}$ で, 再発は21例, 再発率は87.5\%であった. そのう ち $\mathrm{n}($ (一) 11例中, 再発は10例, 再発率は $91.0 \%$ あっ た. $\mathrm{n}(+) 13$ 例中, 再発は11例, 再発率は $84.6 \%$ で, リンパ節転移の有無による再発率に有意差を認めな かった（p>0.10）. 術後 3 年以内の早期の再発率が $75.0 \%(18 / 24)$ と高率で，(14)腸間膜根部リンパ節再発 7 例, 肺・肝・骨転移 8 例, 特殊な腹腔内播種 3 例と さまざまな再発様式を示した（図10-2）。

全 67 症例の 5 , 術後 3 年以上経過例での再発は 9 例で，(14)腸間膜根部リンパ節再発が 6 例 $66.7 \%$ 占め た。これら 6 例のリンパ節郭清は，すべて(14)腸間膜根 部リンパ節右側片側だけの不徹底な郭清症例であった 
図10-1 膵蔵浸潤を認めない症例の十二指腸漫潤リンパ節転移と再発様式 $(n=43)$

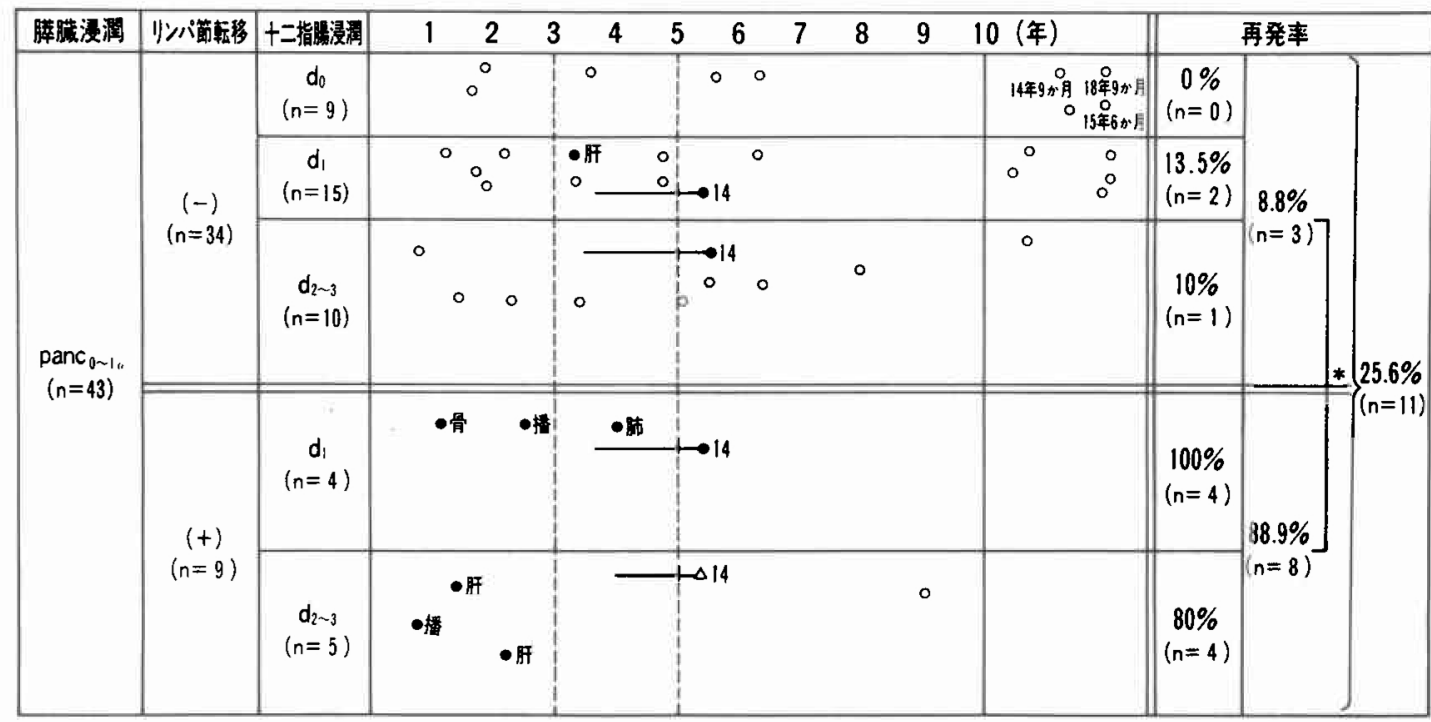

$* p<0.001$

図10-2 膵膈漫潤症例のリンパ節転移と再発様式 $(n=24)$

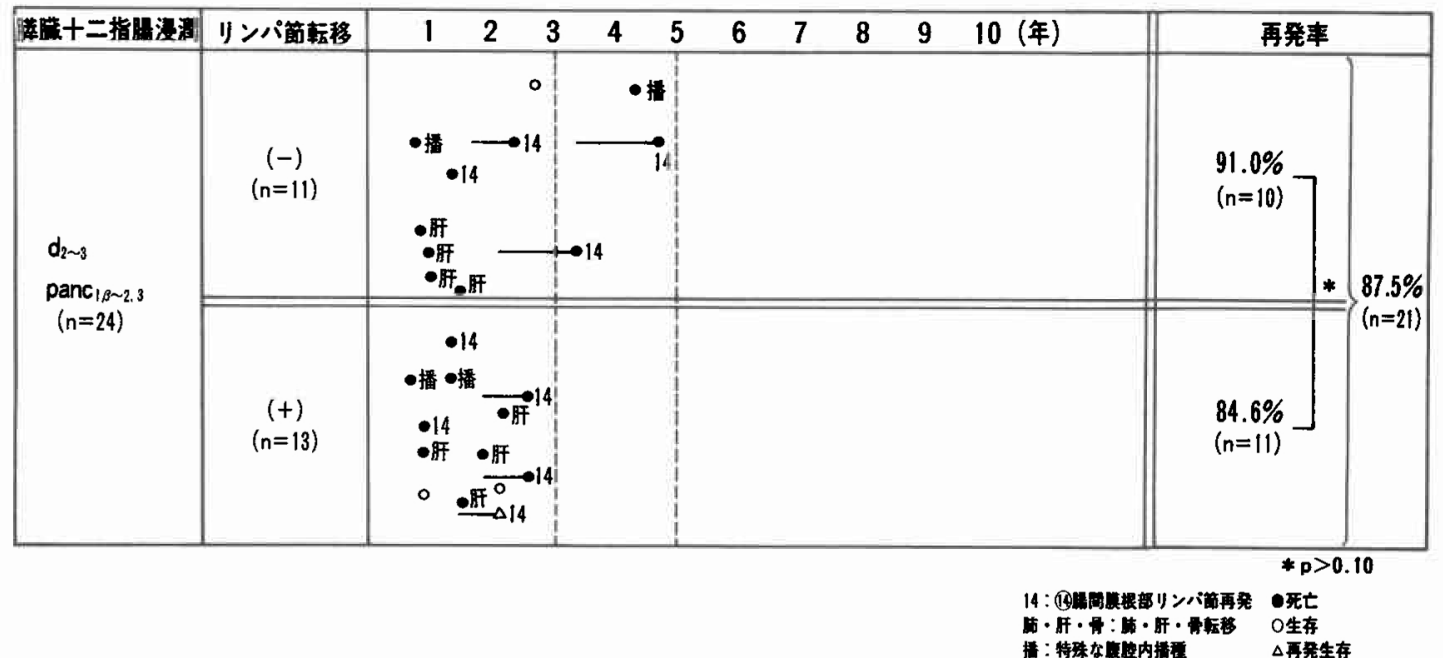

(図10-1, 2).

4）第 2 群以上とくに(14)腸間膜根部リンパ節の重点 的郭清を施行した18例のリンパ節転移状況

乳頭部癌に(14)腸間膜根部リンパ節再発が特徽的で あったことから，第 2 群以上とくに(14)腸間膜根部リン パ節を重点的に郭清した。これら18例のリンパ節転移 状況は, (13)a 27.8\%, (13b 5.6\%, (17)a 5.6\%, (12) 0\%,

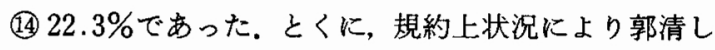
なくてもよいとされる(14)aに11.1\%，(14) と に.6\%，(14) dに5.6\%の計 $22.3 \%$ 転移を認めた（表 6 ）.

考案

乳頭部癌は, 他の膵頭領域癌に比べると切除率, 遠 隔成績とすに良好なのは周知の事実である、最近の報 告では各施設でも $90 \%$ 前後の切除率を举げており7, 教室の成績から切除率の推移をふりか古ってみても， 1978 年 $86.1 \%^{87}, 1981$ 年 $87.5 \%^{7)}, 1984$ 年 $92.4 \%^{9)}, 1988$ 年 $94.1 \%$ 10年間に $8.0 \%$ 切除率向上をみたことに なる。一方，遠隔成績では 5 年生存率 $67.5 \%$ と良好な 
表 6 第 2 群以上とくに(14)腸間膜根部リンパ節重点的 郭清例 $(n=18)$ のリンパ節転移率

\begin{tabular}{|c|c|c|c|c|c|}
\hline 群别 & \multicolumn{2}{|c|}{ 郭清用リンバ野名 } & \multirow{2}{*}{$\begin{array}{c}\text { 転移隔性例 } \\
5 \\
1\end{array}$} & \multicolumn{2}{|c|}{ 転移军 $(\%)$} \\
\hline 第 & $\begin{array}{r}\text { (13)膵䫓後部 } \\
\text { リンパ節 }\end{array}$ & 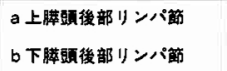 & & $\begin{array}{c}27.8 \\
5.6\end{array}$ & 33.4 \\
\hline 群 & $\begin{array}{l}\text { (17)膵碩前部 } \\
\text { リンバ節 }\end{array}$ & 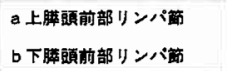 & $\begin{array}{l}1 \\
0\end{array}$ & & \\
\hline 第 & $\begin{array}{l}\text { (12)肝+二指霷間膜内 } \\
\text { リンバ渻 }\end{array}$ & 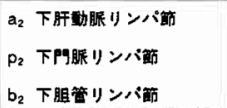 & $\begin{array}{l}0 \\
0 \\
0\end{array}$ & 0 & \\
\hline 群 & 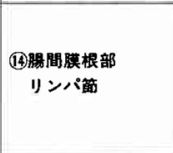 & 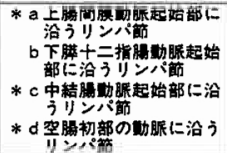 & $\begin{array}{l}2 \\
0 \\
1 \\
1\end{array}$ & $\begin{array}{c}11.1 \\
0 \\
5.6 \\
5.6\end{array}$ & 22.3 \\
\hline
\end{tabular}

報告もある ${ }^{10)}$. 教室でも，5年生存率は1981年36\%7か ら1988年55.1\%へと著しく向上した. しかし，多数の 要因が相互に複雑に関与しあう乳頭部癌では予後規定 因子，再発様式とも充分解明されていないのが現状で ある ${ }^{11)}$. 多くの項目のらち生存期間に対しどの項目が 重要でどの程度影響するかる明らかにするには，単独 または $2 \sim 3$ の項目の単純な比較では困難で, 多変量 解析が適している.しかし, 従来の多変量解析では生 存中の症例や観察不能例のため対象数が少なくなり, 対象がさほど多くない乳頭部癌の予後規定因子の解析 には適さない. Coxの提唱した比例ハザード法 ${ }^{12)}$ は重 回帰分析などの多変量解析之生命表法の両方の特長を そな学て和り，生存期間に対する各項目の影響を適格 にとらえ, 特定の項目の重みを推定したり, 全項目を 考慮した影響力の推定も可能である.しかも対象例の 観察期間が異なっていても全症例の結果を使用するこ とが可能なため, 比較的対象が少ないにもかかわらず， 検討項目が多数ある乳頭部癌の予後規定因子の解析に は最も適していると思われた ${ }^{13) 14)}$. そこでこの比例八 ザード法を用いて予後規定因子の解析を行った。

1. 予後規定因子について

（1）膵臓漫潤：諸家 ${ }^{71 ~ 11) 15) ~ 18) ~}$ 同様, 脈管漫潤陽性 率, リンパ節転移率は膵臓浸潤と強く相関し, 膵藏実 質への浸潤を認めると生存率る不良であった。ところ が現在の規約では，癌浸潤が膵実質に達しないものと 脺央質に達するが $5 \mathrm{~mm}$ 末満のものをあわせて $\mathrm{panc}_{1}$ と規定しており，膵実質浸潤に対する規定がきわめて あいまいである。そこで panc $_{1}$ を癌浸潤が膵実質へ達 するか否かで panc $_{1} \alpha$, panc $_{1} \beta$ とに厳密に規定し, 予後 規定因子としての検討を行った。 5 年生存率は $\mathrm{panc}_{0}$
$82.6 \%, \mathrm{panc}_{1} \alpha 71.4 \%$ と良好であったのに対し, $\mathrm{panc}_{1}$ p $0 \%, \operatorname{panc}_{2,3} 27.8 \%$ と有意に不良で，脺臓浸潤を同 様に規定した吉田ら ${ }^{18)}$ の成績と同じ結果を示した．脺 奏質への癌浸潤を厳密に規定した結果，予後が明瞭に 二極分化されたと思われた。ささらに， $\operatorname{panc}_{1} \beta$ に進展す ると pn(十)さえも20.0\%となった. 中村ら ${ }^{8)}$, 佐藤ら ${ }^{16)}$ の報告するごとく，予後良好な乳頭部癌といえども， 膵実質に癌が浸潤すると生物学的悪性度の高い膵癌の 様相を呈してくると思われた。また，Coxの比例八 ザード法により求めた回㷌係数も $\mathrm{panc}_{0}-0.549$, $\mathrm{panc}_{1} \alpha-0.011$ と予後良好であることを示したのに対 し, $\operatorname{panc}_{1} \beta 1.337$ と大く予後不良を示した，有意性 検定の指標となる $\chi^{2}$ 値は14.812とリンパ節転移に次 いで有意な統計量で, 諸家7) 11)15) 17)が共通して報告す るごとく膵葴浸潤が重要な予後規定因子であると考え られた。

（2）十二指腸浸潤：われわれの教室では従来より Oddi 筋の“barrier”としての存在に着目し, 病理学的 進展様式と遠隔成績の両面から検討してきた。規約で いら $\mathrm{d}_{0} 9$ 例は, 全例脈管浸潤, リンパ節転移を認めず, リンパ節郭清の程度にかかわらず生存中であり，早期 癌の特徵を備えていると思われた 告7) 9)11)151 18) と同様に十二指腸浸潤と脈管浸潤陽性 率, リンパ節転移率は強く相関し, Oddi 筋を越えて癌 が進展すると脈管浸潤陽性率，リンパ節転移率ともに 上异した。 $\mathrm{d}_{0}, \mathrm{~d}_{1}$ の生存率は良好で, 脈管浸潤陽性率, リンパ節転移率ともに低く，長期生存の背景因子とな り竞ると思われたが，予後規定因子としての十二指腸 漫潤の $\chi^{2}$ 值は小さく，吉田ら ${ }^{18)}$ の報告と同様に有意な 予後規定因子ではないと考学られた。

（3）リンパ節転移：n（一)の 5 年生存率は $73.5 \%$ と 良好であるのに対して，n（十）では24.6\%と不良で

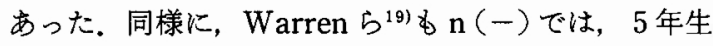
存率 $40.0 \%$ であるのに対して，n $(+)$ では9.8\%と著 しい差を認めたと報告している、リンパ節転移の有無 による回帰係数の差は大きく，予後を明瞭に二分する ことを示した， $\chi^{2}$ 值む 24.873 , 検索項目中最大值を 示した. 水本ら ${ }^{201}$ はリンパ節転移と予後との間には関 係がないと述べているが，リンパ節転移は生存期間へ の影響が最も大きく, 有意な予後規定因子と思われた。

（4）肉眼型: 十二指腸, 膵臟への癌の進展度と肉眼 型との関係は, 強い相関を示し, 癌が進展するにつれ, 尰瘤形成群から潰瘍形成群が増古予後不良であること 
は諸家の一致した見解である7 11115/ 18)20) 24). しかし， 癌の発生部位により, 十二指腸粘膜面からみた肉眼型 に差異が生じるのは当然で, 肉眼型のみから進行度を 類推し予後を論ずることは森岡ら22)の述べるように適 当ではないと思われた，予後規定因子としての $\chi^{2}$ 值は 小さく，肉眼型の違いが予後を規定しないと思われた。

(5) 脈管漫潤：脈管浸潤の有無や程度は, リンパ行 性，血行性転移の潜在性をる示しらるもので，一般に は吉田 ${ }^{18)}$ ，松野ら ${ }^{23)}$ の述ぺるよらに生存期間に大き な影響を与兄る。予後規定因子としてみると，リンパ 管浸潤, 静脈浸潤とも $\chi^{2}$ 值は小さく, 乳頭部癌におい ては脈管漫潤が，有意には予後を規定しないと考えら れた。

（6）組織型, 浸潤増殖様式, 腫瘍の大ささ：組織 型では乳頭腺癌が52例と多かったが，その他の組織型 と生存率に有意差が認められなかった。 $\chi^{2}$ 値は小さ く, 組織型の違いが有意に予後を規定することはない と思われた。浸潤増殖様式では INF $\alpha$ の 5 年生存率が $100 \%$ ，回㷌係数一 1.030 で予後良好であることを示し た。荒木ら ${ }^{24)}$ は浸潤増殖様式を重要な予後規定因子と 報告しているが， $\chi^{2}$ 值は小さく浸潤増殖様式の違いが 予後を規定しないと思われた。畽場の大きさ別の生存

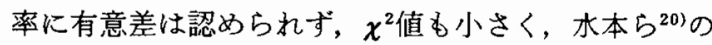
述べるように腫瘍の大きさが予後を規定することはな いと思われた。

（7）リンパ節の郭清度：(14)腸間膜根部リンパ節への 転移率が $22.3 \%$ と第 1 群である113脺頭後部リンパ節に 次いで高いことから、リンパ節の郭清度による治療効 果を検討した， $\mathrm{R}_{1}$ と $\mathrm{R}_{2,3}$ では，回帰係数もプラスに働 き予後不良であることを示したが，(14腸間膜根部リン パ節を重点的に郭清した $\mathrm{R}_{2,3}$ *で，回帰保数はマイナス を示し予後良好であることを示した，今回，リンパ節 郭清度の違いによる治療効果に有意差が得られなかっ た一つの原因は, $\mathrm{R}_{2,3}$ *群の観察期間が最長 5 年と短く 生存率の差の検定に必要な症例数を満たしていないた

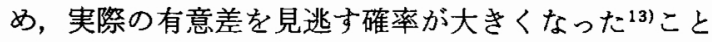
によると思われた。

\section{2. 再発様式}

乳頭部癌の再発様式の特徵は, 他の膵頭部領域癌に 比べると, 米村ら ${ }^{25}$ 子剖検例で指摘しているように(14) 腸間膜根部のリンバ節再発と考えられた。とくに，膵 滅浸潤を認めない症例の特徵は, リンパ節転移により 予後が規定され, 術後晚期の(14腸間膜構部リンパ節再 発であると思われた。これらはすべて米村ら ${ }^{25)}$ 報告
しているょうに，(14)腸間膜根部のリンパ節郭清が不十 分な症例であった。しかも同リンパ節を重点的に郭清 すると $22.3 \%$ と高率に転移を認めた。松野ら ${ }^{23)}$ ，吉田 ら 18 もとれぞれ(14)腸間膜根部リンパ節に17.9\%, $20.0 \%$ と高い転移率を認め，リンパ節転移を認める症 例は治瘾切除例であっても，予後不良であったと報告 している.Evans $5^{26)}$, 三輪ら ${ }^{27)}$ の色素を膵頭部に注入 した研究や，出来ら ${ }^{28}$ の剖検例での膵頭部のリンパ経 路に関する報告は，(14)腸間膜根部への高率なリンパ節 転移・再発を裏付ける根拠となるものと思われた。さ らに, われわれの教室では, 吉田ら ${ }^{18)}$, 松野ら ${ }^{23)}$, 永川 と同様に, $\mathrm{R}_{2}$ のリンパ節郭清とくに(14)腸間膜根部リン 八節を重点的に郭清する膵頭十二指腸切除術を膵臓浸 潤の有無にかかわらず行い，治療効果を検討してきた が，今回有意な結果は得られなかった。この理由は, 観察期間が短く症例が少ないために治療効果の有意差 判定が困難ということのほかに, 膵臓浸潤例では，リ ンパ節転移にかかわらず予後不良で，(14腸間膜根部り ンパ節再発のほか血行性転移も早期から認めたことか ら，リンパ節郭清のみでは遠隔成績の向上は望めない ことを示唆していると考兄られた。しかし, 永川299は(14) 腸間膜根部リンパ節を重点的に郭清した結果， 5 年生 存率が $17.6 \%$ から $66.1 \%$ と向上したと報告しており, さらに(14腸間膜根部への高率なリンパ節転移率・再発 率を考兄ると，少なくとも膵臓浸潤を認めない症例の 遠隔成績の向上のためには, (14)腸間膜根部リンパ節の 重点的な郭清は必要と思われた ${ }^{300}$.

最後に, 特殊な再発様式として, 初回手術時に術中 散布したと考えられる早期の腹腔内播種を 6 例経験し たが，いたずらに腹腔内操作での生検は撖に慎むべき と考えられた。

\section{結論}

乳頭部癌67例を対象に, 規約上の項目について, 生 存期間へ及ぼす影響の大きさ Cox の比例ハザード 法で解析し，予後規定因子を検討した。ささらに進展度 別の再発様式の特徵を検討した結果，以下の結論を得 た。

1.リンパ節転移, 膵臓浸潤の順で有意な予後規定因 子であった。

2. 膵蔵浸潤, 十二指腸浸潤と脈管浸潤陽性率, リン パ節転移率, 肉眼型は強い相関を示し, 膵臟浸潤を認 めると神経周囲浸潤さえ認め, 潰瘍形成群が增加した。

3. (14)腸間膜根部リンパ節に $22.3 \%$ と高率に転移を 認めた。 
4. 再発様式としては術後 3 年前後の(14腸間膜根部 リンパ節再発が $19.4 \%$ と特徵的であった。

5. 膵臓浸潤を認めない症例は,リンパ節転移が予後 を大きく規定した，再発様式の特徵は晚期の(14)腸間膜 構部リンパ節再発であった。

6. 膵藏浸潤を認めると, (14)腸間膜根部リンパ節再発 のほかに，血行性転移为認め, リンパ節転移にもかか わらず予後不良で, 3 年以内の早期に $75.0 \%$ が再発し た。

稿を終觉るにあたり, 直接御指導, 御校閲をいただいた東 京女子医科大学消化器外科学教室 羽生富士夫教授, 中村 光司助教授, 今泉俊秀講師, 病理学的御指導を戴いた吉川達 也講師, 御助言をいただいた膵・胆道ダループの諸兄, 統計 解析の御援助をいただいた塩野義製薬解析センターの諸氏 に深く感謝いたします。

なお，本論文の要旨は第88回日本外科学会総会(1988年 4 月新渴), 第32回日本消化器外科学会総会(1988年 6 月金沢) に颃いて発表した。

\section{文献}

1）斉藤洋一, 大柳治正, 藤原英利添加: 胆道癌長期生 存例の全国集計。胆と萃 $8: 1249-1314,1987$

2）山中恒夫, 上野規男, 木村 健添：超音波内視鏡 による十二指腸乳頭部癌浸潤範团判定. Gastroenterol Endosc 28:3100-3109, 1986

3）山雄健次, 中澤三郎, 内藤靖夫ほか: 乳頭部癌の内 視鏡診断一その有用性と限界. 消化器科 8 : 267-274，1988

4) Fortner JG : Regional resection of cancer of the pancreas: A new surgical approach. Surgery $73: 307-320,1973$

5）新井田達雄, 羽生富士夫, 今泉俊秀ほか：膵頭十二 指腸切除術500例の早期合併症の検討. 膵臓 3 ： $27-34,1988$

6) 日本胆道外科研究会編：外科・病理胆道癌取扱い 規約. 第 2 版, 金原出版, 東京, 1984

7) 今泉俊秀: 乳頭膨大部癌の臨床病理学的検討一特 に肉眼型括よび進展形式について一, 東京女医大 誌 $51: 1115-1131,1981$

8) 中村光司, 今泉俊秀, 高田忠敬任か: 十二指腸乳頭 部癌の臨床病理学的検討一とくに予後に影響を招 上涪寸諸因子について一。目消外会誌 $11: 941$ -946, 1978

9）羽生富士夫, 今泉俊秀, 中村光司ほか：早期乳頭部 癌の概念。胆と膵 $5: 847-852,1984$

10）高木國夫, 高橋 孝, 大橋一郎ほか: 乳頭部癌の診 断々治療. 外科診療 $21: 407-414,1979$

11）市場康之, 田中恒夫, 藤井康史注か：十二指腸乳頭 部癌手術症例の検討一進展様式之予後の関保につ いて一. 日消外会誌 $20 ： 1858-1862,1987$
12) Cox DR: Regression models and life tables. J Roy Statist Soc B 34:187-220, 1972

13）富永祐民：治療効果判定のための実用統計学。第 4 版, 蟹書房, 東京, 1987, p77-134

14）浜辺 豊, 佐藤美晴, 斉藤洋一：食道癌の予後因子 に関する臨床病理学的研究。日外会誌 $89: 805$ $-814,1988$

15）吉田 正：乳頭部癌の進展度診断における臨床病 理学的検討一とくに組織学的進展度と画像診断々 の比較検討一. 久留米医会誌 $49: 1358-1371$, 1986

16）佐藤寿雄, 松野正紀, 山内英生ほか：膵頭部領域癌 切除術後に打ける長期生存例の検討。外科 45 ： 259-266, 1983

17）山口晃弘, 蜂須賀喜多男, 磯谷正敏ほか：十二指腸 乳頭部癌の組織学的検討一特に組織像と予後との 関連について一, 日消外会誌 $15 ： 1231-1237$, 1982

18）吉田 正, 中山和道, 嬉野二郎ほか：胆道癌長期生 存例の検討一乳頭部癌. 胆子膵 $8: 1205-1210$, 1987

19) Warren KW, Choe DS, Plaza J: Results of radical resection for periampullary cancer. Ann Surg 181:534-540, 1975

20）水本龍二, 世古口務: 乳頭部癌の進展度と手術成 績：胆と脺 $5: 875-880,1984$

21）黑田 慧, 木村 理, 和田祥之ほか：乳頭部癌. 外 科診療 $41: 323-329,1987$

22）森岡恭彦, 和田祥之, 黒田 慧：乳頭部癌の臨床病 理学的特徵と手術成績. 肝胆膵 $6: 273-280$, 1983

23）松野正紀，小針雅男, 山内英生ほか：十二指腸乳頭 部癌の外科治療. 胆と膵 $5: 869-874,1984$

24）荒木京二郎, 岡島邦雄, 畐士原彰ほか：Vater 乳頭 部癌 40 例の臨床病理学的検討. 外科 $44: 1493$ $-1502,1982$

25）米村 豊, 永川宅和, 宮崎逸夫：膵頭部領域癌拡大 郭清術症例の検討ーリンパ節転移を中心に一，日 消外会誌 $15: 31-39,1982$

26) Evans BP, Oshsner A : The gross anatomy of the lymphatics of the human pancreas. Surgery $36: 177-191,1954$

27）三輪晃一，三村 䅱，山岸 满汪か：膵頭部領域癌 のリンパ節転移, 乳頭部癌, 膵内胆管癌を中心に. 癌の臨 $25: 21-26,1979$

28）出来尚史, 佐藤達夫：臨床解剖からみたリンバ系 （I）上腸間膜リンパ系について。リンパ学 6: $33-37,1983$

29）永川宅和：膵頭部領域癌に対する扗大郭清術。外 科治療 $52: 189-196,1985$

30）今泉俊秀, 新井田達雄, 羽生富士夫：乳頭部癌の外 科治療成績。消化器科 $8: 305-314,1988$ 